\title{
Luna Celosa
}

\author{
Oswaldo Ríos Carrascal \\ Especialista en Docencia Universitaria \\ Estudiante Maestría en Educación \\ Universidad Autónoma de Bucaramanga \\ orios544@unab.edu.co \\ Recibido el 28 de marzo 2014 \\ Aprobado el 16 de mayo 2014
}

La luna celosa en la noche alumbraba,

Cientos de luceros bien la acompañaban

En el cielo brillaban unas cuantas estrellas

Que coqueteaban sin cesar hasta en la alborada

En el cielo están pero no sé donde

Tantas ilusiones

Tantas cosas vagas,

Aquellos recuerdos que mande al olvido

Allá están muy lejos

En inmensa calma

Aquellos que daño me hicieron 
En noches aciagas...

No los considero como parte de mi alma.

En cambio recordarte a ti

Me hace placentero

Aunque no estés conmigo

En las noches iluminadas,

La luna celosa se muestra renuente

A seguir brillando en las madrugadas...

Oh luna celosa no te afanes tanto

Consuélate con saber

Que una vez te alegré con mis risas, con mis cantos,

Olvídate que otras veces sufrí y duré muchas horas

Sumergido en llanto....

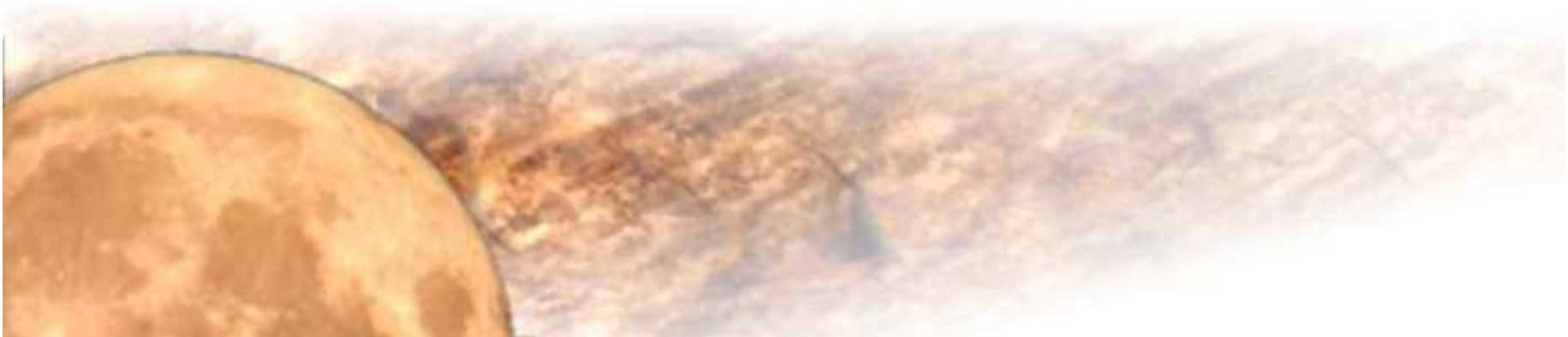

